\title{
Biocatalysis for biomass valorization
}

\author{
Joyeeta Mukherjee ${ }^{1}$ and Munishwar Nath Gupta ${ }^{2 *}$
}

\begin{abstract}
Biocatalysis is a more sustainable alternative to chemical catalysis. While trying to obtain value added products from a biomass, looking beyond lignocelluloses (e.g.: marine polysaccharides, plant gums) may pay dividend. Many waste materials can be looked upon as a source of oil. Oil can be a rich source of diverse types of chemicals apart from biodiesel. Similarly, glycerol, the common by-product during biodiesel production, irrespective of the oil used, itself is the starting material of many products. Biocatalysis already is a viable option for the biodiesel formation step and may have a greater potential scope in glycerol chemistry. The ways to obtain the necessary biocatalysts and tailoring a given biocatalyst for a particular activity in the context of biomass valorization are discussed.
\end{abstract}

Keywords: Biofuels, Polysaccharide degradation, Biocatalysis, Biotransformation, Catalytic promiscuity, Enzymes in low water media

Biocatalysis, in general, is considered to be a more suitable alternative to chemical catalysis $[1,2]$. Hence valorization of biomass using biocatalysts enhances the sustainability quotient of such processes. This commentary article presents an overview of the use of biocatalysis as applied to the conversion of biomass into value added products.

\section{Types of/sources of biomass}

Looking up an excellent book published in 1995 [3], we find biomass defined as "all organic matter that grows by the photosynthetic conversion of solar energy". The net carbon production is highest in forests $\left(\sim 33 \times 10^{9}\right.$ tons/year) but is followed by another impressive figure of $25 \times 10^{9}$ tons/year corresponding to marine sources. The lignocellulosic material present in the plants has attracted sufficient attention from the beginning; interest in the marine sources has also intensified in the last several decades. Still, enzymology of cellulases is more extensively studied than chitinases. Much less work has been done on agar/alginate or carrageenan degrading enzymes [4]. At present, polysaccharide degrading biocatalysts lead the list of biocatalysts used for the conversion of biomass into fuels and fine chemicals. It is not just

\footnotetext{
*Correspondence: munishwar48@yahoo.co.uk

${ }^{2}$ Department of Biochemical Engineering and Biotechnology, Indian

Institute of Technology Delhi, Hauz Khas, New Delhi 110016, India

Full list of author information is available at the end of the article
}

degradation, modification of polysaccharides is equally important. For example, modification of xanthan which is used in food processing, textile, paper and paint industry is a valuable transformation [3]. Acylation of xanthan alters its functional properties in its applications. There is a scope for biocatalysts there. Some green shoots in this approach are beginning to appear [5].

Within plants, oil has become a starting material for the synthesis of numerous valuable chemicals. Oil itself is not generally treated as a biomass. However, let us base our discussion on a broader view of biomass: a renewable resource especially if it is not exploited yet and/or treated as a waste material. Metzger and Eissen pointed out that rapeseed oil has the lowest gross energy requirement (GER) of all the base chemicals [6]. (Base chemicals are chemicals produced $>$ million ton per year worldwide and are starting materials for a large number of other products). The review also points out that "approximately $51 \%$ of the renewable raw materials used at present in Germany are fats and oils, carbohydrates are included in the other 6\%!" [6]. Apart from biodiesel, obtaining biosurfactants, engineered lipids (for nutritional purposes) and new materials from fats/oils are all industrial level processes. It may be pertinent to point out that while it is still not a practical method, aqueous enzyme oil extraction (again the role of biocatalysts!) remain a very desirable technique to develop [7,8]. More important, the concept of biorefinary is tied up with deriving platform 
molecules from rest of the plant material after the seeds are harvested [9].

It has been pointed out in recent years that enough oil is present in sources not tapped so far. This is not just a reference to the inedible oils like from jatropha and castor which have been fairly well studied for conversion to biodiesel and biolubricants [10-12]. The oils present in spent coffee grounds, bird feather and waste from tobacco industry constitute renewable resources [13-15]. With oil from spent coffee grounds, facile conversion to biodiesel has been reported [16]. Japan's experience has shown that oil from kitchen waste is a viable source for conversion to biodiesel [17]. Glycerol is the common by-product in all conversions. So, these renewable resources can also be tapped for all the excellent products which have been obtained from glycerol so far [18-20] and that list is growing [21].

Glycerol is a part of a rather small list of "green solvents". Given its high viscosity, it has not become popular as a reaction medium. However, there are reports which suggest that as a reaction medium for biocatalysis in low water media, glycerol does offer significant potential $[18$, 19].

Recent interest in microalgae as a source of oil for conversion to biodiesel [22-25] shows that search for new renewable resources is a continuous exercise. It is interesting to recall that National Renewable Energy Laboratory had published a "close out report" on biodiesel from algae in July 1998 on a program funded from 1978 to 1996. To quote from that report: "The cost analyses for large-scale microalgae production evolved from rather superficial analyses in the 1970s to the much more detailed and sophisticated studies conducted during the 1980s. A major conclusion from these analyses is that there is little prospect for any alternatives to the open pond designs, given the low cost requirements associated with fuel production. The factors that most influence cost are biological, and not engineering-related. These analyses point to the need for highly productive organisms capable of near-theoretical levels of conversion of sunlight to biomass. Even with aggressive assumptions about biological productivity, we project costs for biodiesel which are two times higher than current petroleum diesel fuel costs" [26].

Sometimes, we have to wait before the time for a particular idea arrives! May be the valorization of food waste is one such idea [27, 28]. Seaweed lipids constitute another renewable source of diverse compounds of nutritional value or with very interesting physiological effects [29].

\section{Choosing/tailoring biocatalysts}

While currently available information tools have facilitated cross-fertilization of ideas from different areas, it also has created what biochemists call feedback inhibition. Too much information of varied reliability still makes it difficult to identify the right alternative. Here is a quick list of choices available while deciding about the use of a biocatalyst for valorization of biomass (Table 1).

While earlier, one was limited by enzymes readily available from microbial/plant/animal sources, that is no longer the constraint. Cloning a gene in a suitable expression system is now a fairly well established route. E. coli remains the first choice as the host expression system. In case of the enzyme ending up in inclusion bodies (IBs), many refolding strategies are available [30, 31]. Lately, IBs are no longer looked upon as completely inactive proteins. Many turn out to have significant biological activity and IB formation is being exploited as carrier free immobilization [31]. In some cases it is necessary to obtain the enzyme in a post-translationally modified

Table 1 Selecting a biocatalyst for biomass valorization

\begin{tabular}{|c|c|}
\hline & Comments \\
\hline \multicolumn{2}{|l|}{ (A) Source of biocatalyst } \\
\hline Whole cell or free enzyme & Whole cells can also be used in permeabilized form [52] \\
\hline Wild type or mutant enzyme produced by rDNA technology & Some organisms are frequently used as the source for industrial enzymes [53] \\
\hline Refolded from IBs or use of IBs itself & $\begin{array}{l}\text { Choice of the host is important. For enzymes where activity depends upon post trans- } \\
\text { lational modification, higher organisms are used as host expression systems [54] }\end{array}$ \\
\hline \multicolumn{2}{|l|}{ (B) Free or immobilized form } \\
\hline Soluble conjugates & $\begin{array}{l}\text { For insoluble substrates (which is often the case with biomass), soluble conjugates [55] } \\
\text { or enzymes in membrane reactors are preferred [56] }\end{array}$ \\
\hline Carrier free or insoluble support & Enzyme aggregates like CLEA [57] or CLEC [58] have high volumetric activity \\
\hline (C) Operational stability & This may be different from storage stability [36] \\
\hline (D) Reaction medium & The use of co-solvents is under exploited [59] \\
\hline (E) Normal or promiscuous activity & $\begin{array}{l}\text { As more enzymes, engineered for better promiscuous activity, become available, this } \\
\text { application may increase }[60,61]\end{array}$ \\
\hline
\end{tabular}


form. In such cases other host expression systems have to be used.

In many cases, whole cells as biocatalysts turn out to be a more economical option when mass transfer constraints are either not significant or can be minimized by the use of permeabilized cells. Many redox enzymes require co-enzymes, the latter either has to be regenerated [32] or whole cells become an attractive option. Unfortunately, in such cases permeabilization of the cells is ruled out as low molecular weight co-enzymes would diffuse out. Both enzymes and whole cells can be either used in free form or immobilized form [33, 34].

Given the complex nature of the biomass, the stability of the biocatalyst is a crucial parameter. It is necessary to be clear about the stability data available from the literature or the vendor. The thermal stability measured in aqueous buffers is not necessarily a reliable parameter. Measurement of the operational stability with a substrate dissolved/suspended in a mixture as close to the biomass composition may be a good starting point. It is not a good idea to base this choice on the basis of the optimum temperature as that depends upon both the assay composition and time period of assay measurements [35, 36].

Today, one can carry out biocatalytic processes in a wide range of non aqueous media. This is especially useful with biomass as a substrate since pre-incubation of the biomass with the reaction medium sometime can serve as a pre-treatment step. For biocatalytic processes in dry organic solvents, choosing the right water activity for the reaction medium and maintaining it throughout the process is important [37, 38].

It is now known that classical microbiological techniques for searching for suitable microbial sources do not tap a vast amount of microbial diversity. Metagenomics (initially called environmental DNA technology) is a powerful tool to search out for a suitable biocatalyst [39].

Directed evolution compliments protein engineering in tailoring enzymes for a particular purpose. Stability and specificity both can be altered [40-42]. Contrary to earlier belief, new enzymes continue to evolve [43].

The range of substrates on which enzymes can work has become considerably enlarged with the discovery of catalytic promiscuity [44-47]. In such cases, very unrelated substrates bind to the same active site. The binding and catalysis generally involves qualitatively or even quantitatively different active site residues. For example, till few years back, if one wanted a biocatalyst for a redox reaction, one would naturally choose a suitable redox enzyme. That still may be the best option but not necessarily the only option. Enzymes can catalyse reactions which are not expected according to their EC classification [46]. For example, recently we showed that a simple lipase can carry out Cannizaro reaction [47]. Not only that, starting from an aldehyde, formation of alcohol and/or acid could be controlled by a suitable choice of lipase and/or a reaction medium. At present, such accidental catalytic promiscuity generally is not of significant level for biomass valorization. However, there are enough results which show that both protein engineering and directed evolution can create a biocatalyst with a significant level of promiscuous activity $[44,45]$.

It is believed that "accidental catalytic promiscuity" results inherently from how new enzymes evolve [48]. Dellus-Gur et al. [49] have discussed how functional innovation (during evolution) depends upon protein structure. Conformational plasticity (which results in various conformations of a protein co-existing) correlates positively with new catalytic functions emerging. More interesting is the hypothesis that stability (opposite of plasticity) can also promote innovability/evolvability. According to these authors "Stability promotes evolvability only if stability is an additive, global parameter, whereby stabilizing mutations in one region (e.g., a protein's scaffold) readily compensate for the destabilizing effects of mutations in other locations (e.g., in the active site region). While this is the prevailing model, can it be taken for granted? In some proteins, higher stability is mediated by mutations in residues that mediate function, suggesting that stability and function do trade off" [49]. The above illustrates how our understanding of protein evolution can further help in engineering biocatalysts for an application such as biomass valorization.

\section{Conclusion}

Clearly, valorization of biomass is at the heart of developing sustainable chemical processes. The concept of biorefinary is based upon that. It is interesting to note that the area of process intensification is bringing chemists, engineers and biologists together [50]. Process intensification initially focussed upon reduction in the size of the process equipment but has evolved into a more inclusive version. The aim is to further develop multifunctional reactors. Microwaves, ultrasound and solar energy are emphasized as alternative energy sources. In the context of the present commentary, carrier free immobilization reduces reactor volume, biocatalyst formats like combiCLEAs facilitate the design of multifunctional reactors [51].

\section{Authors' contributions}

$J M$ searched the literature, took part in the discussions during drafting and helped with the formatting. MNG shaped the final draft and proof read the article before submission. Both authors read and approved the final manuscript. 


\section{Author details}

1 Department of Chemistry, Indian Institute of Technology Delhi, Hauz Khas, New Delhi 110016, India. ${ }^{2}$ Department of Biochemical Engineering and Biotechnology, Indian Institute of Technology Delhi, Hauz Khas, New Delhi 110016, India.

\section{Acknowledgements}

We acknowledge financial support from the Department of Science and Technology (DST), Govt. of India [Grant No.: SR/SO/BB-68/2010]. JM thanks the Council of Scientific and Industrial Research [Govt. of India] for the Senior Research Fellowship. We acknowledge interesting discussions on biomass valorization with Prof. P. Mishra (Dept. of Biochem. Engg. and Biotechnol., IIT Delhi, India).

\section{Compliance with ethical guidelines}

\section{Competing interests}

The authors declare that they have no competing interests.

Received: 20 March 2015 Accepted: 9 June 2015

Published online: 18 June 2015

\section{References}

1. Schmid A, Dordick JS, Hauer B, Kiener A, Wubbolts M, Witholt B (2001) Industrial biocatalysis: today and tomorrow. Nature 409:258-268

2. Malhotra D, Mukherjee J, Gupta MN (2015) Sustainability of biocatalytic processes. In: Letcher TM, Scott JL, Patterson DA (eds) Chemical process technology for a sustainable future. Royal Society of Chemistry, Cambridge, pp 390-423

3. Glazer AN, Nikaido H (1995) Microbial biotechnology: fundamentals of applied microbiology. Freeman and Co., New York, p 364

4. Wood WA, Kellogg ST (1988) Biomass, methods in enzymology, vol 161. Academic press Inc., New York

5. Bajpai $P$ (2012) Biotechnology for paper and pulp processing. Springer Science + Business Media, LLC, New York, pp 317-326

6. Metzger JO, Eissen M (2004) Concepts on the contribution of chemistry to a sustainable development. Renewable raw materials. C R Chemie 7:569-581

7. Rosenthal A, Pyle DL, Niranjan K (1996) Aqueous enzymatic processes for edible oil extraction. Enzyme Microb Technol 19:402-420

8. Sharma A, Khare SK, Gupta MN (2002) Enzyme-assisted aqueous extraction of peanut oil. J Am Oil Chem Soc 79:215-218

9. Wettstein SG, Alonso DM, Gurbuz El, Dumesic JA (2012) A roadmap for conversion of lignocellulosics biomass to chemicals and fuels. Curr Opin Chem Eng 1:218-224

10. Shah S, Gupta MN (2007) Lipase catalyzed preparation of biodiesel from Jatropha oil in a solvent free system. Process Biochem 42:409-414

11. Koh MY, Ghazi ITM (2011) A review of biodiesel production from Jatropha curcas L oil. Renew Sust Energy Rev 15:2240-2251

12. Malhotra D, Mukherjee J, Gupta MN (2015) Lipase catalyzed transesterification of castor oil by straight chain higher alcohols. J Biosci Bioeng 119:280-283

13. Veljković VB, Lakićević SH, Stamenković OH, Todorović ZB, Lazic ML (2006) Biodiesel production from tobacco (Nicotiana tabacum L.) seed oil with a high content of free fatty acids. Fuel 85:2671-2675

14. Kondamudi N, Strull N, Misra M, Mohaptra S (2009) A green process for biodiesel from feather meal. J Agric Food Chem 57:6163-6166

15. Encinar JM, Snchez N, Martnez G, Garcia L (2011) Study of biodiesel production from animal fats with high free fatty acid content. Bioresour Technol 102:10907-10914

16. Banerjee A, Singh V, Solanki K, Mukherjee J, Gupta MN (2013) Combiprotein coated microcrystals of lipases for production of biodiesel from oil from spent coffee grounds. Sust Chem Processes 1:14

17. Shimada Y, Watanabe Y, Sugihara A, Tominaga Y (2002) Enzymatic alcoholysis for biodiesel fuel production and application of the reaction to oil processing. J Mol Catal B Enzym 17:133-142

18. Torres S, Castro GR (2004) Non-aqueous biocatalysis in homogeneous solvent systems. Food Technol Biotechnol 42:271-277
19. Diaz-Alvarez AE, Francos J, Lastra-Barreira B, Crochet P, Cadierno V (2011) Glycerol and derived solvents: new sustainable reaction media for organic synthesis. Chem Commun 47:6208-6227

20. Len C, Luque R (2014) Continuous flow transformations of glycerol to valuable products: an overview. Sust Chem Processes 2:1

21. Canabarro N, Soares JF, Anchieta CG, Kelling CS, Mazutti MA (2013) Thermochemical processes for biofuels production from biomass. Sust Chem Processes 1:22

22. Hu Q, Sommerfield M, Jarvis E, Girardi M, Posewitz M, Siebert M et al (2008) Microalgal triacylglycerols as feedstocks for biofuel production: perspectives and advances. Plant J 54:621-639

23. Mata TM, Martins AA, Caetano NS (2010) Microalgae for biodiesel production and other applications: a review. Renew Sust Energy Rev 14:217-232

24. Chuck CJ, Wagner JL, Jenkins RW (2015) Biofuels from microalgae. In: Letcher TM, Scott JL, Patterson DA (eds) Chemical process technology for a sustainable future. Royal Society of Chemistry, Cambridge, pp 425-442

25. Alabi AO, Tampier M, Bibeau E (2009) Microalgae technologies and processes for biofuels/bioenergy production in british Columbia: current technology, suitability and barriers to implementation. British Columbia Innovation Council, Victoria

26. Sheehan J, Dunahay T, Benemann J, Roessler P (1998) A look back at the US department of energy's aquatic species program-biodiesel from algae. National Renewable Energy Laboratory, Colorado

27. Luque R, Clark JH (2013) Valorisation of food residues: waste to wealth using green chemical technologies. Sust Chem Processes 1:10

28. Karmee S, Lin C (2014) Valorisation of food waste to biofuel: current trends and technological challenges. Sust Chem Processes 2:22

29. Narayana B, Kumar CS, Sashima T, Maeda H, Hasokawa M, Miyashita K (2008) Composition, functionality and potential applications of seaweed lipids. In: Hou CT, Shaw JF (eds) Biocatalysis and bioenergy. Wiley and Sons Inc., New Jersey, pp 463-490

30. Clark EB (2001) Protein refolding for industrial processes. Curr Opin Biotechnol 12:202-207

31. Mukherjee J, Gupta MN (2015) Paradigm shifts in our views on inclusion bodies. Curr Biochem Eng 2:1-9

32. Torrelo G, Hanefeld U, Hollmann F (2015) Biocatalysis. Catal Lett 145:309-345

33. Hanefeld U, Gardossi L, Magner E (2009) Understanding enzyme immobilization. Chem Soc Rev 38:453-468

34. Leak DJ, Feng X, Emanuelsson EAC (2015) Enzyme biotransformations and reactors. In: Letcher TM, Scott JL, Patterson DA (eds) Chemical process technology for a sustainable future. Royal Society of Chemistry, Cambridge, pp 320-346

35. Purich DL (2010) Enzyme kinetics: catalysis and control. Academic, London

36. Halling PJ, Gupta MN (2014) Measurement and reporting of data in applied biocatalysis. Perspect Sci 1:98-109

37. Halling PJ (1992) Salt hydrates for water activity control with biocatalysts in organic media. Biotechnol Tech 6:271-276

38. Vulfson EN, Halling PJ, Holland HL (2001) Enzymes in nonaqueous solvents: methods and protocol. Humana Press, New Jersey

39. Tringe SG, Rubin EM (2005) Metagenomics: DNA sequencing of environmental samples. Nat Rev Genet 6:805-814

40. Arnold FH, Georgiou G (2003) Directed evolution screening and selection methods. Humana Press, Towota

41. Goldsmith M, Tawfik DS (2012) Directed enzyme evolution: beyond the low-hanging fruit. Curr Opin Struc Biol 22:406-412

42. Porter JL, Boon PL, Murray TP, Huber T, Collyer CA, Ollis DL (2015) Directed evolution of new and improved enzyme functions using an evolutionary intermediate and multidirectional search. ACS Chem Biol 10:611-621

43. Janssen DB, Dinkla IJT, Poerlands GJ, Terpstra P (2005) Bacterial degradation of xenobiotic compounds: evolution and distribution of novel enzyme activities. Environ Microbiol 7:1868-1882

44. Kapoor M, Gupta MN (2012) Lipase promiscuity and its biochemical applications. Process Biochem 47:555-569

45. Busto E, Gotor-Fernandez V, Gotor V (2010) Hydrolases: catalytically promiscuous enzymes for non-conventional reactions in organic synthesis. Chem Soc Rev 39:4504-4523

46. Arora B, Mukherjee J, Gupta MN (2014) Enzyme promiscuity: using the dark side of enzyme specificity in white biotechnology. Sust Chem Processes 2:25 
47. Arora B, Pandey PS, Gupta MN (2014) Lipase catalyzed Cannizzaro-type reaction with substituted benzaldehydes in water. Tetrahedron Lett 55:3920-3922

48. Khersonsky O, Roodveldt C, Tawfik DS (2006) Enzyme promiscuity: evolutionary and mechanistic aspects. Curr Opin Chem Biol 10:498-508

49. Dellus-Gur E, Toth-Petroczy A, Elias M, Tawfik DS (2013) What makes a protein fold amenable to functional innovation? Fold parity and stability trade-offs. J Mol Biol 425:2609-2621

50. Boodhoo K, Harvey A (eds) (2013) Process intensification for green chemistry; engineering solution for sustainable chemical processing. Wiley and Sons Ltd., London

51. Dalal S, Kapoor M, Gupta MN (2007) Preparation and characterization of combi-CLEAs catalyzing multiple non-cascade reactions. J Mol Catal B Enzym 44:128-132

52. Raghava S, Gupta MN (2009) Tuning permeabilization of microbial cells by three-phase partitioning. Anal Biochem 385:20-25

53. Wubbolts MG, Bucke C, Bielecki S (2000) How to get the biocatalyst. In: Straathof AJJ, Adlercreutz A (eds) Applied biocatalysis. Harwood Academic Publishers, Amsterdam, pp 157-158

54. Greene JJ (2004) Host cell compatibility in protein expression. Methods Mol Biol 267:3-14

55. Roy I, Sharma S, Gupta MN (2004) Smart biocatalysts: design and applications. Adv Biochem Eng Biotechnol 86:159-189
56. Pederson S, Christensen MW (2000) Immobilized biocatalysts. In: Straathof AJJ, Adlercreutz A (eds) Applied biocatalysis. Harwood Academic Publishers, Amsterdam, pp 213-228

57. Minteer SM (ed) (2011) Enzyme stabilization and immobilization: methods and protocols. Humana Press, Totowa

58. Montanez-Clemente I, Alvira E, Macias M, Ferrer A, Fonceca M, Rodriguez $J$ et al (2002) Enzyme activation in organic solvents: co-lyophilization of subtilisin Carlsberg with methyl-betacyclodextrin renders an enzyme catalyst more active than the crosslinked enzyme crystals. Biotechnol Bioeng 78:53-59

59. Roy I, Mukherjee J, Gupta MN (2013) High activity preparations of lipases and proteases for catalysis in low water containing organic solvents and ionic liquids. In: Guisan JM (ed) Immobilization of enzymes and cells, 3rd edn. Humana Press, New York, pp 275-284

60. Hult K, Berglund P (2007) Enzyme promiscuity: mechanism and applications. Trends Biotechnol 25:231-238

61. Kourist R, Bartsch S, Fransson L, Hult K, Bornscheuer UT (2008) Understanding promiscuous amidase activity of an esterase from Bacillus subtilis. Chembiochem 9:67-69

\section{Publish with ChemistryCentral and every scientist can read your work free of charge \\ "Open access provides opportunities to our colleagues in other parts of the globe, by allowing anyone to view the content free of charge."}

W. Jeffery Hurst, The Hershey Company.

- available free of charge to the entire scientific community

- peer reviewed and published immediately upon acceptance

- cited in PubMed and archived on PubMed Central

- yours - you keep the copyright

Submit your manuscript here:

http://www.chemistrycentral.com/manuscript/<smiles>c1ccccc1</smiles>

ChemistryCentral 